\title{
An Investigation on Students' Perception of Possible Factors That Affect Their Academic Performance at A University of Technology
}

\author{
Stephanie Caroline Samuel ${ }^{1} \&$ Ferina Marimuthu $^{2}$ \\ ${ }^{1}$ Department of Management Accounting, Faculty of Accounting and Informatics, Durban University of Technology, \\ Kwa-Zulu Natal, South Africa \\ ${ }^{2}$ Department of Financial Accounting, Faculty of Accounting and Informatics, Durban University of Technology, \\ Kwa-Zulu Natal, South Africa
}

Correspondence: Stephanie Caroline Samuel, Department of Management Accounting, Faculty of Accounting and Informatics, Durban University of Technology, Kwa-Zulu Natal, South Africa.

Received: September 28, 2021

Accepted: November 8, 2021

Online Published: November 9, 2021

doi:10.5430/ijhe.v11n3p26

URL: https://doi.org/10.5430/ijhe.v11n3p26

\begin{abstract}
The successful completion of a module measures student performance at tertiary institutions through ascertaining predetermined pass percentages. The lack of conceptualization of content by a student, may affect the students' academic achievement. This paper aimed to investigate students' perceptions on the factors that may impact Cost Accounting students' performance and determine if these factors have a significant association with a student's performance. The independent variables identified were attendance, age, gender, grade 12 results and language, whilst the dependent variable was academic performance in the Cost Accounting module. Using a sample of 180 students registered for Cost Accounting II in their second year of study, the data collected from the questionnaires were analyzed with descriptive and inferential statistics. The study found that student attendance has a positive impact on student performance in the module. The findings of this study may be useful to higher education institutions and academics as it highlights the factors that influence students' academic achievement.
\end{abstract}

Keywords: accounting, cost accounting II, academic achievement, student success, attendance, throughput

\section{Introduction}

South African universities are characterized by relatively low success rates, compared to a desired national norm of 80 per cent. As a result, the graduation rate for students in three-year degree programmes in contact education is well below the international benchmark of 25 per cent. Serious concerns are highlighted about the productivity of the system and the high costs to government and institutions from poor student success rates and raise substantial equity issues. The reasons for this poor performance are complex. Amongst other, early-warning systems and other methods of recognizing students who need support are inadequate. Factors affecting student success are diverse and include insufficient funding, poor living conditions, and inadequate support for academic and social adjustment to university life (DHET 2013).

Tertiary institutions in South Africa have predetermined benchmarks to assess a reasonable throughput rate that applies to students in any module. Within a module, the adherence to the benchmark is directly proportionate to the academic performance of students. Measuring students' academic performance can be challenging since student performance is a product of socio-economic, psychological and environmental factors.

The Department of Higher Education in South Africa, identified that from 88771 enrolled students, an overall throughput rate of 9.2\% was achieved (Khuluvhe and Mathibe 2021). Male students from the enrolled group (35 046) showed a throughput rate of $6.4 \%$ whilst female (53 725) students exhibited a throughput rate of $11 \%$. More specifically, finance, economics and accounting fields showed an overall throughput rate of $7.7 \%$ based on an average enrollment of 5445 tertiary students. From this, it is evident that the accounting field exhibits a lower throughput rate than the national benchmark. In light of this, it is necessary to investigate why only $7.7 \%$ of students registered in this field cannot complete their programme in the designated time frame. Nationally, Kwa-Zulu Natal shows a throughput rate lower than the national standard, which is $7.9 \%$. Consequently, this study focuses on a module within a three-year diploma programme, intending to identify the reasons why students struggle to achieve acceptable grades. 
Many empirical studies have been conducted on student performance at universities worldwide (Baard et al. 2010; Bossaert, Doumen, Buyse and Verschueren 2011). However, there are limited studies conducted on the performance of Accounting students at a South African University of Technology (UoT), according to Dobkin, Gil and Marion (2010); Teixeira (2013); Papageorgiou and Halabi (2014); Jansen and De Villiers (2016). Baard, Steenkamp, Frick and Kidd (2010). These authors identified a need to examine possible factors that may impact the performance of students in tertiary education. This paper investigates the association between student academic performance and attendance, age, gender, grade 12 results and language. The outcomes from this study will provide a better understanding of what contributes to academic success hence providing much-needed insight for tertiary educators and assist in improving throughput in a given module.

Regression analysis was implemented to test the five hypotheses generated for this study. The hypotheses are as follows:

$\mathrm{H}^{1}$ Attendance, which states that there is a positive relationship between student attendance and student performance;

$\mathrm{H}^{2}$ Age, which states that there is no difference between students' performance and age;

$\mathrm{H}^{3}$ Gender, which states that female students perform better than male students;

$\mathrm{H}^{4}$ Grade 12, which states that an above $60 \%$ pass in Mathematics, English and Accounting in grade 12 would result in a student performing better at tertiary level;

$\mathrm{H}^{5}$ Language; which states that students who speak English as their home language will perform better than those who do not.

Whilst this study is conducted at a UoT with Accounting students, it will contribute towards the existing body of knowledge by examining the impact of potential factors identified, and how these factors may influence student academic performance in a UoT in South Africa.

The paper first identifies and discusses the dependent variable, which is performance. A theoretical underpinning will link the factors of academic performance to various theories identified by surveying existing literature. Thereafter, the independent variables, which are the factors affecting student performance, are identified and discussed.

Performance is an individual's attempt to meet a standard within a particular organization, and is usually linked to a specified outcome (Campbell and Wiernik 2015). Motowildo, Borman, and Schmit (1997) indicated that performance results from an assigned task that is carried out with an evaluative component. Campbell and Wiernik (2015) showed that academic performance is measured by a student's ability to apply knowledge gained through a test or examination. Academic achievement usually requires capabilities such as critical thinking to achieve the optimum result desired. Therefore, the measurement of academic achievement varies and would be specific to the outcome of the assessment. (Steinmayr, Meibner, Weidinger and Wirthwein 2015).

The paper employed the theoretical underpinning from various studies, which were Elger's (2007) theory of performance (ToP), Astin's (1984) theory of student engagement, Tinto's (1975; 1993) integration theory and Bean's $(1985 ; 1995)$ psychological theory.

Elger (2007) explains that many attributes contribute to performance; just as a computer needs various parts to function, so does performance. Consequently, an individual's level of performance is directly proportional to the attribute attained and therefore stimulates the succession through performance levels.

The first was "Mind-set". This technique suggests a student's performance is linked to a student's attitude towards a particular subject/activity (Elger 2007). The technique highlights factors that may impact student performance. If a student has a bad attitude towards their education, they will choose not to attend lectures regularly, affecting academic performance.

The second technique is "Environment"; one's surroundings generally affect individual performance. This would mean the environment surrounding an individual's life could impact one's performance ability (Elger 2007). However, these situations could have either a positive or negative influence. Also, a student's mental and physical well-being is highlighted as being an aspect that contributes to performance. Due to older students being mature individuals, they may take their education more seriously than the younger generation.

The final technique identified by Elger (2007) was "Reflective practice", this technique suggests experience, past knowledge or skill (or lack of thereof) to be an indicator of performance. For example, if a student performed poorly in grade 12, they can consciously decide to improve their results when at university. Similarly, if a student has achieved outstanding results, they will then adapt their learning styles to cope with tertiary course work. 
The subject matter theory and the resource theory was generated by Astin (1984). The theories state that the attendance of a student during lectures assists with the process of learning. If the contact time available for the student is fully utilized, this would positively influence the teaching and learning process.

Tinto's integration theory (Tinto 1975) suggests that student retention rates are a significant indicator of student academic performance, particularly at tertiary institutions. Tinto's integration theory, used by Berge and Haung (2004), McCubbin (2003) and Seidman (1996), recognized pre-entry college attributes, such as background, academic ability, race, gender and prior schooling, as contributing factors to a student's academic performance.

Tinto's (1993) model of student departure specifies some attributes that assist in predicting student success. One of the contributing factors towards student attainment at an institution is prior schooling. Factors such as academic achievement at high school, first year at university, and social experiences, would affect a student's ability to flourish or be fruitless in their endeavours.

Lastly, Bean's $(1985 ; 1995)$ psychological theory theorized that older students find coping harder than their younger classmates. This difficulty was attributed to external circumstances, which are linked to age. Although there are many other theories, this paper focuses only on academic performance in the Accounting discipline and has discussed five of the most relevant theories.

Campbell and Wiernik (2015) describe performance as the method one follows under prescribed conditions to achieve a specific goal. If a learner wants to complete a course and become a graduate, the student needs to perform according to the examination body's standards. Using examinations as a means of assessment measures the success of a course (Motowildo et al. 1997). The following sections explain the factors said to impact student academic performance.

Five factors are identified in this study to influence student academic performance. These factors are attendance at lectures, the age group of a student, gender, home/first language and grade 12 results. Similar studies such as Hoskins, Newstead and Denise (1997) and the Jansen and De Villiers (2016) study, examined the aforementioned factors that impact student academic performance.

Student attendance is one factor contributing to the successful completion of a course (Blerkom 2001, Traphagan et al. 2009 and Cortright et al. 2011). Authors such as Marburger (2006), Dobkin et al. (2010), Cortright et al. (2011), Schmulian and Coetzee (2011), Teixeira (2013) and Alanzi (2015) found a positive correlation between student attendance and student academic performance. The studies show that lack of attendance hinders the students' ability due to limited exposure to course content.

Studies such as Johnson et al. (2002) and Clark and Latshaw (2012) indicated no correlation between student attendance and student performance. This is in contradiction to the findings of Marburger (2006), Dobkin et al. (2010), Cortright et al. (2011), Schmulian and Coetzee (2011), Teixeira (2013) and Alanzi (2015).

Reasons why students did not attend lectures, were found by Blerkom (2001) and Schmulian and Coetzee (2011), and were attributed to illness, timetable clashes, traffic and transport issues and over-sleeping. In contrast, Paisey and Paisey (2004) found that the reasons for students' poor attendance were due to part-time work, course work, illness and personal reasons (which included hangovers).

The abovementioned studies have identified that the lack of class attendance negatively impacts a student's performance through various groups of students in different environments. Regardless of why students miss class, the studies suggested that learners who do not attend class sacrifice valuable information and notes during lecture time. This would mean a lack of understanding which could ultimately lead to poor performance. Attendance is thus an important factor when determining student success and performance.

$\mathrm{H}^{1}$ is thus stated as follows: There is a positive relationship between student attendance and student performance.

The age of a student is the second factor believed to impact on student academic performance. Three categories define the age groups of students; these categories are mature-aged students, traditional students and non-traditional students. Mature-aged students are those students who have work experience and are older (McCune et al. 2010). Traditional students, on the other hand, are students who proceed to tertiary education directly after the completion of grade 12 (Ballester 2010); A non-traditional student is a student that would attend a private college to upgrade their education with the relevant credits before proceeding to a UoT (Cantwell et al. 2001).

Richardson (1994), Richardson and King (1998), Richardson (2006) and McCune et al. (2010) found that mature-aged students perform better academically when compared to younger students in the same circumstances. This is attributed to the sense of responsibility and wisdom that these students may possess. Additionally, Cantwell et 
al. (2001) found that non-traditional students do not perform and mature-aged students in the same grouping. Studies show that mature-aged students outperform other age categories of students.

Younger students were found to be superior academically in studies conducted by Hoskins et al. (1997), Nyikahadzoi et al. (2013), Papageorgiou and Halabi (2014) and Jansen and De Villiers (2016). The aforementioned studies indicated that younger students have an advantage of continuity, seeing as they progress directly into tertiary from high school. However, Ballester (2010) found no difference in the academic performance of mature-aged, traditional and non-traditional students.

$\mathrm{H}^{2}$ is thus stated as follows: There is no difference between students' performance and age.

The gender of a student is one of the factors believed to have a possible impact on academic performance. This section reviews literature that investigates the academic performance of male and female students.

Borg and Stranahan (2002b), Nyikahadzoi et al. (2013) and Jansen and De Villiers (2016) all found that male students seem to perform significantly better than female students in the same grouping and environment. The reason for male students outperforming female students were inconclusive amongst these studies.

However, studies by Borg and Stranahan (2002a), Marks (2008) and Marks (2010) have found that female students perform better academically when to compared to male students in the same grouping and environment. The reasons provided by these studies were that female students have a sense of maturity and responsibility compared to male students of the same age category. Marks (2008) also indicated that although male students previously outperformed female students, the gap has significantly decreased as female students show better academic performance in theoretical subjects when compared to male students in the same classroom.

Some studies indicated that there is no difference in academic performance when analyzed according to gender. These studies were Durden and Ellis (1995) and Papageorgiou and Halabi (2014), which showed no significant difference in academic performance between male and female students.

Female students seem to outperform male students in theory-based subjects, reading, and stressful situations. However, male students seem to excel in practical subjects, such as Mathematics. In addition, a few studies (Durden and Ellis 1995; Papageorgiou and Halabi 2014) found no significant differences between the genders and their academic performance.

$\mathrm{H}^{3}$ is thus stated as follows: female students perform better than male students.

The next factor believed to impact the academic performance of a student is their final high school diploma, which is referred to as their grade 12 results. In South Africa, the term "grade 12" refers to the year in which a secondary school student completes high school. Grade 12 achievement is commonly a predictor or measure of success regarding most endeavours pursued afterwards. This section discusses those studies which isolated grade 12 student achievement as a predictor of success when scholars enter or apply for entrance into tertiary institutions.

Evans (2000) and Bitzer and Troskie-De Bruin (2004) have found that a student's achievement in high school is a strong predictor of academic success or failure when entering tertiary education. More specifically, when enrolled in an accounting course at tertiary, the achievement of a student in high school mathematics and accounting showed the achievement of a student in tertiary accounting modules (Du Plessis et al. 2005, Ballester 2010, Kukreja and Aali 2013).

Stainbank (2013) and Papageorgiou and Halabi (2014) found that a student's performance in high school mathematics showed a significant relationship to accounting students' academic performance at tertiary level. Therefore, prior schooling is directly correlated to academic achievement of a university student. Most studies identified support grade 12 academic achievement being a reliable predictor of tertiary success (Evans 2000; Ballester 2010; Marks 2010). Moreover, mathematics and accounting are identified as predictors of success in accounting modules at tertiary level.

$\mathrm{H}^{5}$ is thus stated as follows: an above $60 \%$ pass in Mathematics, English and Accounting in grade 12 would result in a student performing better in Cost Accounting II at tertiary level.

The final factor believed to impact academic performance is language. South Africa is rich in diversity since it has 11 official languages. English, however, is the language of instruction at most, if not all, educational institutions. This may well obstruct academic success when one cannot articulate the language fluently (Singh 2020).

Studies have indicated that students who speak English as a second language have trouble teaching and learning (Rosenthal et al.1983; Howie 2003). However, other studies, such as Marks (2010), have indicated that students who 
speak English as a second language outperform students who communicate in English as a first language. Moreover, in the Marks (2010) study, non-English speaking students formed a minority in the study's sample population. Du Plessis et al. (2005) could not find any significance between the language barrier and academic performance.

$\mathrm{H}^{5}$ is thus stated as follows: students who speak English as their home language will perform better than those who do not.

\section{Method}

A positivist paradigm was used for this study. The best way to find a relationship between multiple variables is by means of measurement, a quantitative method was chosen. To achieve the aim of the study, a questionnaire was used to collect the required data.

The participants chosen for this study were students at the DUT, who were in their second year of study and were registered for Cost Accounting II in the second semester. All 180 students registered for Cost Accounting II formed the population of this study, and thereafter the census method was employed.

The questionnaire consisted of 51 questions, comprising of open- and closed-ended Likert scale questions. The questionnaire was divided into seven sections, which measured various themes, as illustrated below:
A Background of students;
B Language and how it impacts on learning;
C Attendance and the effect it has on performance;
D Age of a student and whether it impairs or enables a student in the classroom;
E Grade twelve results and the effect thereof on tertiary pass rates;
F Performance of a student; and
G Suggestions for improving performance through attendance and the opinions of the respondents.

The questionnaires were pretested to an expert group of staff members at the DUT. Thereafter, a pilot-test with a sample set of 13 students was conducted.

Due to the student protests, only 165 students were available to respond to the questionnaire. Of the 165 students who answered the questionnaires, seven responses were not valid. Therefore, 158 questionnaires were used for the analysis. The response rate was, therefore, $87.8 \%$.

The data collected from the participants was analyzed using SPSS version 23.0.

To address the research objectives and hypotheses, a deductive approach was selected. An epistemological philosophy was employed as this study uses positivism as interpretivism. Descriptive statistics summarised the respondent's answers to each of the questions as well as measures of variability and central tendency. Statistical testing of the data was done by first formulating hypotheses and testing for significance. Also, the Kolmogorov-Smirnov test was applied when data were ranked. The Mann-Whitney-U test was employed to test any significant differences in responses to gender and home language responses. A correlation matrix was used to test the strength of the relationships between the variables; finally, regression analysis tested the study's five hypotheses.

This study was limited to DUT, in particular, to students in Accounting-related fields. To address validity, a census sample population was selected. To ensure validity, Table 1 displays the results of the Cronbach's alpha test.

Table 1. Cronbach's alpha score for all items which constituted the questionnaire

\begin{tabular}{ll}
\hline Section & Cronbach's Alpha \\
\hline B Language and how it impacts on learning & 0.72 \\
C Attendance and the effect it has on performance & 0.62 \\
D Age of a student and whether it impairs or enables a student in the classroom & 0.58 \\
E Grade twelve results and the effect thereof on tertiary pass rates & 0.71 \\
F Performance of a student & 0.39 \\
G Suggestions for improving performance through attendance and the opinions of the & 0.88 \\
respondents & 0.82 \\
Overall & \\
\hline
\end{tabular}


The reliability scores for all sections exceed or approach the suggested Cronbach's alpha value of 0.600 for a newly developed construct. This indicates a degree of satisfactory, dependable scoring for these sections. Only section F had a score that was lower than the norm. The primary reason for this is that the questions that comprised this section measured various subthemes unrelated to each other. As a result, the value was accepted. To ensure the reliability of responses, a stability coefficient method was used.

\section{Results}

The results are descriptive and indicate the level of agreement students expressed regarding each statement presented. Each statement links to an independent variable that is tested for this study.

Tables 2 and 3 show statements that relate to the independent variables. Students expressed their views on the impact of the individual factors on their performance in Cost Accounting II, which are presented and analyzed according to language and gender. Students' views on what impacts their performance according to gender are presented below.

Table 2 analyzed questions one to five according to gender.

Table 2. Respondents' views on what may improve their Cost Accounting II performance and gender

\begin{tabular}{|c|c|c|c|c|c|c|c|c|c|c|c|}
\hline \multirow[t]{2}{*}{ Statements } & \multicolumn{3}{|l|}{$\begin{array}{l}\text { Male } \\
\mathrm{n}=62\end{array}$} & \multicolumn{3}{|c|}{$\begin{array}{l}\text { Female } \\
\mathrm{n}=84\end{array}$} & \multicolumn{3}{|c|}{$\begin{array}{l}\text { Total } \\
\mathrm{n}=146\end{array}$} & \multicolumn{2}{|c|}{$\begin{array}{l}\text { Mann-Whitney } \\
\text { U test }\end{array}$} \\
\hline & Mean & Median & SD & Mean & Median & SD & Mean & Median & SD & $\mathrm{Z}$ & $\mathrm{P}$ \\
\hline $\begin{array}{l}\text { 1)Attendance at Cost } \\
\text { Accounting } 2 \text { lectures results } \\
\text { in good performance. }\end{array}$ & 3.98 & 4.00 & 0.86 & 4.21 & 4.00 & 0.73 & 4.12 & 4.00 & 0.79 & -1.60 & 0.11 \\
\hline $\begin{array}{l}\text { 2)Age positively impacts on } \\
\text { my performance. }\end{array}$ & 3.69 & 4.00 & 1.33 & 3.08 & 3.00 & 0.97 & 3.34 & 3.50 & 1.17 & -3.41 & $0.00 * * *$ \\
\hline $\begin{array}{l}\text { 3)Female students outperform } \\
\text { male students in Cost } \\
\text { Accounting II. }\end{array}$ & 2.26 & 2.00 & 0.90 & 3.80 & 4.00 & 1.05 & 3.14 & 3.00 & 1.25 & -7.42 & $0.00 * * *$ \\
\hline 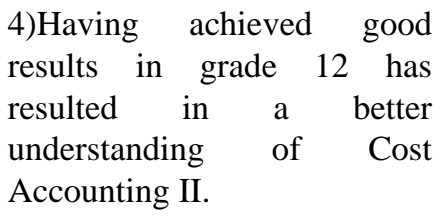 & 3.58 & 3.00 & 0.92 & 3.26 & 3.00 & 0.68 & 3.40 & 3.00 & 0.80 & -2.32 & $0.02 * *$ \\
\hline $\begin{array}{l}\text { 5)Home language does not } \\
\text { affect my performance } \\
\text { negatively. }\end{array}$ & 3.69 & 4.00 & 1.06 & 3.81 & 4.00 & 0.74 & 3.76 & 4.00 & 0.89 & -0.71 & 0.48 \\
\hline$* * *$ Significant at the 0.01 level & & & & & & & & & & & \\
\hline ** Significant at the 0.05 level & & & & & & & & & & & \\
\hline * Significant at the 0.001 level & & & & & & & & & & & \\
\hline
\end{tabular}

A total of 146 students (62 females and 84 males) answered the statements listed above. Table 2 shows overall agreement with statements one and five (median of four). However, in the Mann-Whitney U test, statements one and five from table 2, did not show any significant differences in responses.

Overall, statement two showed some agreement with a median of 3.5, whereas statements two and three showed mostly neutral responses (overall median of three). Statement two showed females felt more neutral (mean of 3.08) on age, positively impacting their performance. Male students showed some agreement with statement two, which is indicated by a mean value of 3.69. The Mann-Whitney $U$ test shows a statistically significant difference between male and female students $(\mathrm{p}<0.01)$, with a higher agreement amongst male students that age positively impacts their performance.

Statement three asked male and female students if they felt that females outperformed males in Cost Accounting II. As expected, males disagreed with a mean value of 2.26. Females showed agreement with a mean value of 3.8. Females believed that they do outperform males in Cost Accounting II. The difference in responses is statistically 
significant at $\mathrm{p}<0.01$. The median of male and female answers to statement three (two and four, respectively) show the difference in opinions between genders.

Statement four shows that male and female students were mostly neutral with their responses (median of three). However, male students showed some agreement (mean of 3.58), whereas female students were more neutral (mean of 3.26). The Mann-Whitney $U$ test shows a statistically significant difference in responses of $p<0.01$ between male and female students. Some male students felt grade 12 results influence performance in Cost Accounting II.

In supporting the significant findings in Table 2, Ballester (2010) found no significant difference in performance between mature- and traditional-aged students when age was considered. Also, Borg and Stranahan (2002a) and Marks $(2008 ; 2010)$ found that female students often outperform male students. Furthermore, Nyikahadzoi et al. (2013) found that male students outperform female students. However, it is important to note that Durden and Ellis (1995) and Papageorgiou and Halabi (2014) did not find significant differences between performance and gender. Evans (2000), Du Plessis et al. (2005), Marks (2010), Stainbank (2013), and Papageorgiou and Halabi (2014) found that grade 12 pass rates are a strong predictor of tertiary academic success.

To refine the findings on student perceptions of the statements presented in Table 2, the next table analyzes the responses according to home language instead of gender.

Table 3 analyzes statements one to five according to respondents' home language.

Table 3. Respondents' views on what may improve their Cost Accounting II performance and language

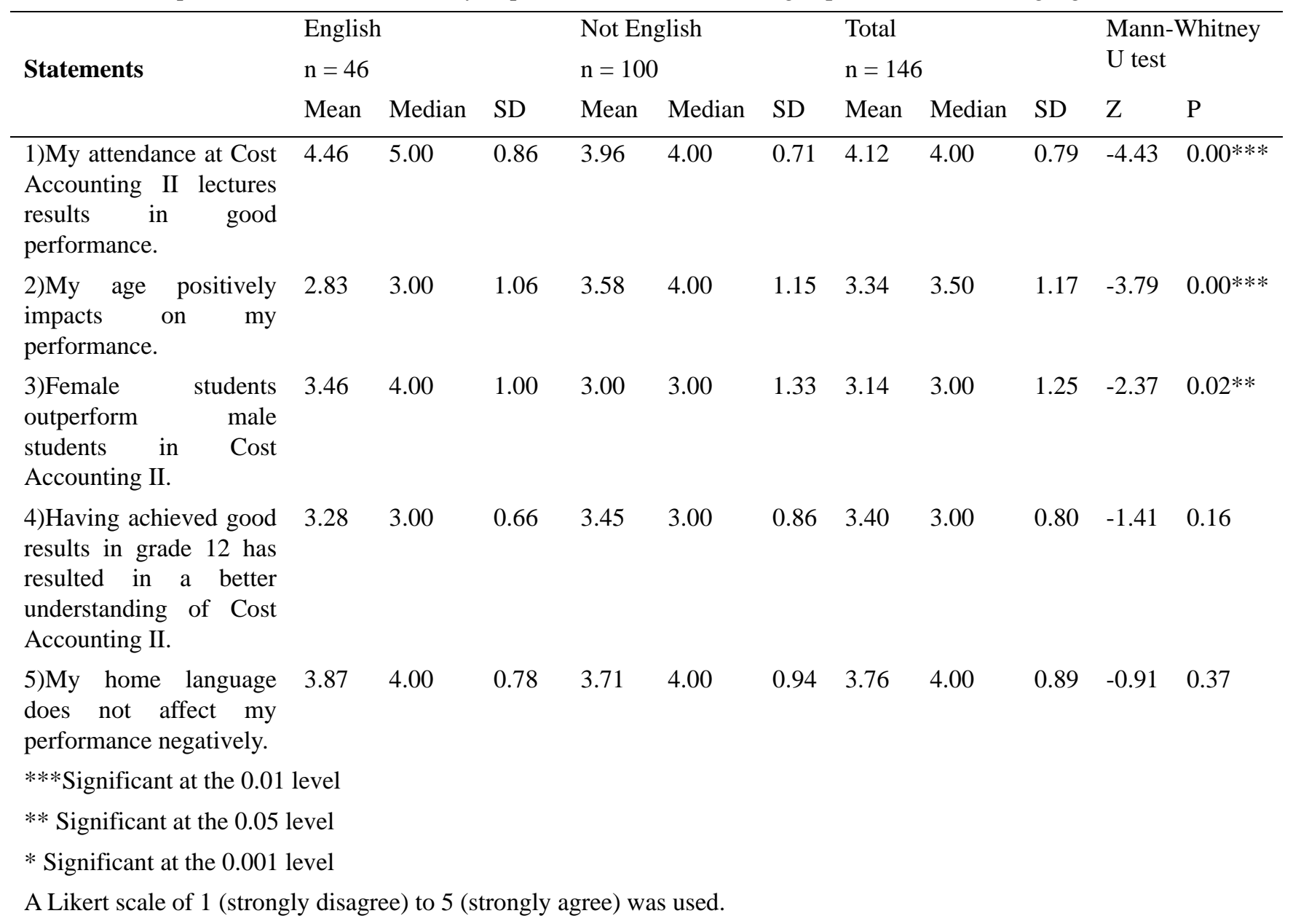

Statement one in table 3 above shows English speaking students strongly agreed (median of five) that attendance positively influences their performance. Non-English speaking students also agreed with statement one (median of four; mean of 3.96). However, English speaking students agreed more (mean of 4.46). The difference in responses is statistically significant $(\mathrm{p}<0.01)$.

Statement two shows non-English speaking students show some agreement (median 4.0). However, the mean value 
for English speaking students shows more disagreement (2.83), whereas non-English speaking students show some agreement (3.58). Furthermore, responses for statement two show statistically significant differences in responses from both groups $(\mathrm{p}<0.01)$, indicating that English speaking students do not feel that their age positively impacts their performance. Statement three found English speaking students mostly agreed (median of four), whereas non-English speaking students felt more neutral (median of three). The Mann-Whitney $U$ test shows a statistically significant difference in responses of $p<0.05$ between the two groups, indicating that most English speaking students felt females outperformed males in Cost Accounting II.

Traphagan et al. (2009), Dobkin et al. (2010), Cortright et al. (2011), Schmulian and Coetzee (2011), Teixeira (2013) and Alanzi (2015) all found that performance is improved through attendance. However, Clark and Latshaw (2012) could not find a significant relationship between class attendance and student performance.

Table 4 shows a correlation matrix between variables.

Table 4. Correlation matrix

\begin{tabular}{llllll}
\hline Percentage & My attendance at & My age & Female students & Having achieved & My home language \\
(i.e. & Cost Accounting & positively & outperform male & good results in grade & does not affect my \\
performance) & $\begin{array}{l}\text { 2 lectures results } \\
\text { impacts on } \\
\text { imfood }\end{array}$ & $\begin{array}{l}\text { my } \\
\text { students in Cost }\end{array}$ & Accounting 2 & better understanding \\
performance & performance & & negatively \\
& & & of Cost Accounting 2 & \\
\hline
\end{tabular}

0)Percentage

1.00

(i.e. performance).

1)My attendance at 0.03

1.00

Cost Accounting 2 lectures results in good performance (H1).

2)My age positively impacts on my performance (H2).

3)Female students outperform male students in Cost Accounting II (H3).

4)Having achieved good results in grade 12 has resulted in a better understanding of Cost Accounting II (H4).

5)My home $0.28^{* *} \quad 0.03$ 1.00 language does not affect performance negatively (H5).

** Significant at the 0.01 level.

* Significant at the 0.05 level (2-tailed).

$0.06 \quad-29 * * \quad-03 \quad 1.00$

- Having a better understanding of course content leads to achieving stronger academic results.

- Percentage refers to percentage achieved in Cost Accounting II by that particular student and is used as a measure of performance. 
A correlation was performed between the dependent (performance) and independent (attendance, age, gender, grade 12 results and language) variables to test the relationships between variables. Responses to statements one to five were analyzed along with actual academic performance.

A correlation analysis was performed to test the strength of the relationship between the variables being analyzed (Greener 2008:62). The relationship found between attendance in Cost Accounting II lectures and the percentage achieved in the module produced a positive correlation at $r=0.03$, but not significant.

The next comparison between percentage achieved in Cost Accounting II and age indicated a strong positively correlated significant relationship between variables of $r=0.28 * *$. A correlation between age and student attendance was positive yet not significant $(\mathrm{r}=0.03)$.

The next correlation was between female students and performance $(r=0.04)$, attendance $\left(r=0.21^{* *}\right)$ and age $(r$ $=0.05)$. All these correlations were positive. Only one relationship with females' attendance correlated significantly with attendance $\left(\mathrm{r}=0.21^{* *}\right)$. This means those female students who performed well felt that it was attributed to consistency in attending lectures.

Thereafter, the impact of grade 12 results on percentage achieved, attendance, age and gender were tested. Accomplishing good results in grade 12 has a direct positive relationship to the percentage achieved in Cost Accounting II $(r=0.01)$, attendance $(r=0.06)$ and age $(r=0.29 * *)$. However, an inverse relationship was recognized when testing grade 12 performance against gender $(\mathrm{r}=-0.03)$. This means that female students, who performed well in grade 12, do not indicate that they would outperform male students in Cost Accounting II. However, only age was significantly correlated with performance in grade 12 at $\mathrm{p}<0.01$.

Lastly, the relationship between language and percentage achieved, attendance, age, gender and grade 12 results were tested. Language and attendance show a positively correlated relationship $\left(r=0.18^{*}\right)$. The relationship between language and attendance shows that language does not impact performance, but attendance positively impacts performance. Also, language and grade 12 results show a strong positive correlation $(\mathrm{r}=0.34 * *)$. The relationship between language and grade 12 results shows that achieving good results in grade 12 impacts positively on performance, irrespective of language of instruction. The relationship between language and attendance was statistically significant at $\mathrm{p}<0.01$ whereas the relationship between language and grade 12 results was significant at $p<0.05$ level. Furthermore, language and age show a positive parallel relationship with performance $(r=0.01)$.

A correlation matrix is not sufficient when analyzing relationships between variables. Hence, regression analysis was conducted to prove or disprove the stated hypotheses.

Table 5 shows the regression analysis performed on statements one to five.

Table 5. Regression analysis

Coefficients

\section{Unstandardized \\ Coefficients}

B

$\mathrm{H}^{1}$ : My attendance at Cost Accounting 2 lectures results in good performance

$\mathrm{H}^{2}$ : My age positively impacts on my performance

$\mathrm{H}^{3}$ : Female students outperform male students in Cost Accounting 2

$\mathrm{H}^{4}$ : Having achieved good results in grade 12 has resulted in a -1.46 better understanding of Cost Accounting 2

$\mathrm{H}^{5}$ : My home language does not affect my performance 1.56 negatively

*** Significant at the 0.01 level.

** Significant at the 0.05 level.

* Significant at the 0.10 level.
Standardized $\quad$ t $\quad$ Sig.

Coefficients

Std. Error Beta

$\begin{array}{llll}1.03 & -0.01 & -0.08 & 0.94\end{array}$

$0.72 \quad 0.32$

$3.440 .00 * * *$

$0.65 \quad 0.02$

$0.17 \quad 0.87$

1.29

$-0.11$

$-1.13 \quad 0.26$

1.04

0.15

$1.50 \quad 0.14$ 
In Table 5, the independent variables (attendance, age, gender, grade 12 results and language) were tested against performance in Cost Accounting II (dependant variable) using regression analysis. $\mathrm{H}^{1}$ shows an inverse relationship between attendance and performance $(B=-0.09)$. Likewise, $\mathrm{H}^{4}$, which theorized between grade 12 results and performance, also shows an inverse relationship $(\mathrm{B}=-1.46)$. This finding implies that students with higher attendance did not necessarily obtain better results. Nor did they feel that grade 12 achievement was a factor related to success in Cost Accounting II. $\mathrm{H}^{1}$ and $\mathrm{H}^{4}$ did not show any statistical significance. Age $\left(\mathrm{H}^{2}\right)$ shows a significant positive $\mathrm{B}=2.49$ value. Therefore, it seems that there is no difference in performance when age is a factor. $\mathrm{H}^{2}$ shows a statistically significant relationship of $\mathrm{p}<0.01$ in Table 5. Thus, it seems that age does not affect student performance in Cost Accounting II. As a result, $\mathrm{H}^{2}$ is accepted.

Regression analysis are very much influenced by the variables. Consequently, mature aged students were removed from the analysis as they were a small number of students (26 of 158), which may have influenced the results presented in Table 5. By removing these students, a more precise indication of relationships between variables are achieved.

Table 6 shows a regression analysis after the mature-aged students were removed from the analysis. Therefore, Table 6 provides further analysis which were only applied to traditional students.

Table 6. Regression analysis excluding mature-aged students

\begin{tabular}{|c|c|c|c|c|c|}
\hline \multicolumn{6}{|l|}{ Coefficients } \\
\hline & \multicolumn{2}{|c|}{ Unstandardized Coefficients } & \multirow{2}{*}{$\begin{array}{l}\text { Standardized } \\
\text { Coefficients } \\
\text { Beta }\end{array}$} & \multirow[t]{2}{*}{$\mathrm{t}$} & \multirow[t]{2}{*}{ Sig. } \\
\hline & B & Std. Error & & & \\
\hline $\begin{array}{l}\mathrm{H}^{1}: \text { My attendance at Cost Accounting } 2 \\
\text { lectures results in good performance }\end{array}$ & 3.04 & 1.16 & 0.28 & 2.62 & $0.01 * * *$ \\
\hline $\begin{array}{l}\mathrm{H}^{2} \text { : My age positively impacts on my } \\
\text { performance }\end{array}$ & 0.62 & 0.81 & 0.08 & 0.76 & 0.45 \\
\hline $\begin{array}{l}\mathrm{H}^{3}: \text { Female students outperform male } \\
\text { students in Cost Accounting } 2\end{array}$ & 0.98 & 0.59 & 0.16 & 1.66 & 0.10 \\
\hline $\begin{array}{l}\mathrm{H}^{4} \text { : Having achieved good results in } \\
\text { grade } 12 \text { has resulted in a better } \\
\text { understanding of Cost Accounting } 2\end{array}$ & -2.30 & 1.21 & -0.20 & -1.91 & $0.06^{*}$ \\
\hline $\begin{array}{l}\mathrm{H}^{5} \text { : My home language does not affect } \\
\text { my performance negatively }\end{array}$ & 2.37 & 0.99 & 0.25 & 2.39 & $0.02 * *$ \\
\hline \multicolumn{6}{|l|}{$* * *$ Significant at the 0.01 level. } \\
\hline \multicolumn{6}{|l|}{ ** Significant at the 0.05 level. } \\
\hline * Significant at the 0.10 level. & & & & & \\
\hline
\end{tabular}

$\mathrm{H}^{1}$ in Table 6 shows that attendance may result in better performance in Cost Accounting II. Also, attendance is statistically significant $(p<0.01)$ and shows a strong beta coefficient $(B=3.04)$ between the independent variable and the dependent variable. The regression analysis indicates that attendance shows a positive parallel relationship with performance in Cost Accounting II. Therefore, $\mathrm{H}^{1}$ can be accepted. $\mathrm{H}^{2}$ in Table 6 shows no statistical significance (0.45) between age and student performance when mature-aged students are removed from the analysis. Thus, age is not a contributing factor to student performance, and $\mathrm{H}^{2}$ can be accepted.

$\mathrm{H}^{3}$ identifies the assumption that females outperform male students in Cost Accounting II. However, $\mathrm{H}^{3}$ did not show any statistical significance when tested using regression analysis and is rejected. The relationship between grade 12 performance and performance in Cost Accounting II shows a negative beta coefficient of -2.30. Therefore, an inverse relationship exists between these variables since students did not feel that their grade 12 results impacted their performance in the module; therefore, $\mathrm{H}^{4}$ can be rejected. Language, which $\mathrm{H}^{5}$ tests, theorized that students who speak English as their home language will perform better in Cost Accounting II than those who do not. The regression analysis show that the statement on language is statistically significant $(p<0.05)$. This means that these students did not perceive that their home language negatively impacted their performance; therefore $\mathrm{H}^{5}$ is rejected. This is illustrated by figure 1 below. 


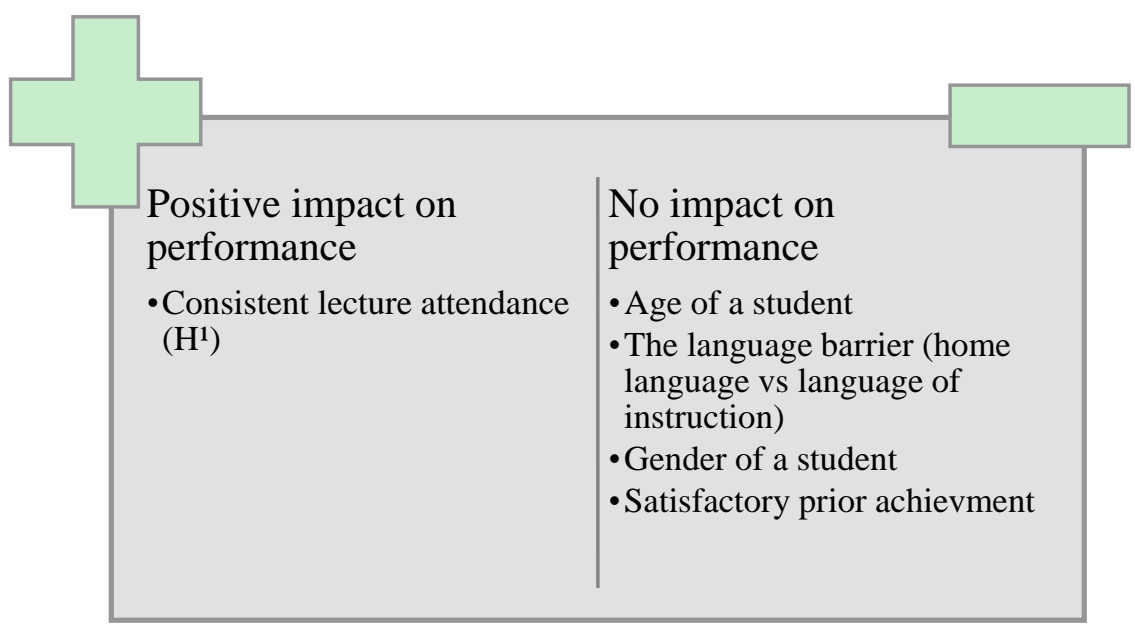

Figure1. Factors that impact on performance

Figure 1 shows that from the hypotheses generated, $\mathrm{H}^{1}$ was the most significant. Students felt that absenteeism from lectures would hinder their understanding and, therefore, their success. Hypotheses $\mathrm{H}^{2}-\mathrm{H}^{5}$ showed that diversity within these categories does not impact performance.

This paper has established that attendance is, therefore, a contributing factor to student performance.

\section{Discussion and Conclusions}

The findings from the correlations that were established showed that performance and attendance are positively correlated. However, the correlation established between attendance and performance was not significant. Furthermore, performance and age are positively correlated and significant. Students' age showed a similar relationship with student performance, which meant that students felt that their age did not negatively affect their performance. Similarly, there was a significantly positive correlation between female students and attendance. Accordingly, female students who attended more lectures showed that attendance positively affected their Cost Accounting II performance.

The correlation between female students and grade 12 performance showed an inverse relationship. This indicated that female students, who performed well in grade 12, might not perform just as well in Cost Accounting II. However, age and gender did not show any significance. On the other hand, age showed a significantly positive correlation with grade 12 performance. Age had a positive relationship with grade 12 performance, which meant that students do not feel that age negatively influences their performance.

A significantly positive correlation between language and attendance showed that attendance positively impacted performance, irrespective of the language of instruction. Likewise, language and grade 12 performance also showed a significantly positive relationship with performance in Cost Accounting II, which indicated that achieving good results in grade 12 had a positive relationship with performance, irrespective of the language of instruction.

A regression analysis was conducted to determine the factors that impacted performance. The first analysis was conducted on the entire group of respondents who participated in the study. The second analysis excluded mature-aged students from the test; significant results were achieved once mature-aged students were excluded.

The regression analysis results indicate that attendance at lectures leads to better performance in Cost Accounting II. Therefore, $\mathrm{H}^{1}$, which stated that higher attendance at lectures is most likely to produce better results, was accepted. The results of the analysis indicated that age does not affect student performance in Cost Accounting II. Therefore, $\mathrm{H}^{2}$, which stated that there is no difference between students' performance when compared using age as a factor, was accepted.

Of the five hypotheses, tested using regression analysis, two were accepted $\left(\mathrm{H}^{1}\right.$ and $\left.\mathrm{H}^{2}\right)$ and three were rejected $\left(\mathrm{H}^{3}\right.$, $\mathrm{H}^{4}$ and $\mathrm{H}^{5}$ ). The objective of this paper was to find which factor significantly impacted student academic performance. Consequently, attendance provided the most statistically significant evidence as a factor that impacts student performance in Cost Accounting II.

This paper aimed to investigate the factors that affected students' academic performance. The findings of the study showed that lecture attendance positively impacts the performance of students. Age, on the other hand, does not 
influence performance. In terms of gender, it was found that female students perform better, but the findings were not significant. Furthermore, the study identified that students grade 12 results did not impact their performance. Furthermore, the language of instruction did not negatively affect student performance. From the study, it is evident that consistent lecture attendance should improve student performance. Therefore, an increase in the number of contact hours of lectures, availability of lecture resources and ensuring compulsory attendance may be a successful attempt to improve student performance.

The study contributes to the existing body of knowledge surrounding the factors which impact student performance. More specifically, the findings of the study can be adapted at other UoTs across South Africa. The study provides academics with insights into factors that impact student academic performance in teaching and learning.

The study is limited to Cost Accounting II students in their second year of study towards their diploma at a UoT; therefore, it cannot be generalized. A suggestion for further research is the impact of compulsory attendance on student performance. The focus area, being student performance and factors impacting performance, could be investigated using many approaches.

\section{References}

Astin, A. (1984). Student involvement: A development theory for Higher Education. Journal of College Student Development, 40, 518-529.

Alanzi, K. A. (2015). Determinants of student performance in cost accounting - further evidence from Kuwait. World Journal of Management, 6(1), 136-152. https://doi.org/10.21102/wjm.2015.03.61.11

Baard, R. S., Steenkamp, L. P., Frick, B. L., \& Kidd, M. (2010). Factors influencing success in first-year Accounting at a South African university: the profile of a successful first-year Accounting student. South African Journal of Accounting Research, 24(1), 129-147. https://doi.org/10.1080/10291954.2009.11435142

Ballester, C. P. M. (2010). Determinants of students' performance in financial Accounting. University of Barcelona, Barcelona: Business Economics Department.

Bean, J. P. (1980). Drop outs and turnover: The synthesis and test of a casual model of student attrition. Research in Higher Education, 12(20), 155-187. https://doi.org/10.1007/BF00976194

Bean, J. P., \& Metzner, B. S. (1985). A conceptual model for non-traditional undergraduate student attrition. Review of Educational Research Winter, 55(4), 485-540. https://doi.org/10.3102/00346543055004485

Berge, Z. L., \& Haung, Y. P. (2004). A model of sustainable student retention: A holistic perspective on the student dropout problem with special attention to e-learning. Doesnews, 13(5), 1-26.

Bitzer, E., \& Troskie-De Bruin, C. (2004). The effect of factors related to prior schooling on student persistence in higher education. South African Journal of Education, 24(2), 119-125.

Blerkom, M. L. (2001). Class attendance in undergraduate courses. The Journal of Psychology, 126(5), 487-494. https://doi.org/10.1080/00223980.1992.10543382

Borg, M. O., \& Stranahan, H. A. (2002a). Personality type and student performance in upper-level economics courses: The importance of race and gender. The Journal of Economic Education, 33(1), 3-14. https://doi.org/10.1080/00223980.1992.10543382

Borg, M. O. M., \& Stranahan, H. (2002b). The effect of gender and race on student performance in principles of economics: the importance of personality type. Applied Economics, 34(5), 589-598. https://doi.org/10.1080/00036840110039249

Bossaert, G., Doumen, E., Buyse, E., \& Verschueren, K. (2011). Predicting students' academic achievement: A two-year longitudinal study. Journal of Applied Developmental Psychology, 32, 47-57. https://doi.org/10.1016/j.appdev.2010.12.002

Campbell, J. P., \& Wiernik, B. M. (2015). The modeling and assessment of work performance. Annual Review of $\begin{array}{llll}\text { Organisational Psychology and Organisational Behaviour, } & \text { 2, }\end{array}$ https://doi.org/10.1146/annurev-orgpsych-032414-111427

Cantwell, R., Archer, J., \& Bourke, S. (2001). A comparison of the academic experiences and achievement of university students entering by traditional and non-traditional means. Assessment \& Evaluation in Higher Education, 26(3), 221-234. https://doi.org/10.1080/02602930120052387 
Clark, S. D., \& Latshaw, C. A. (2012). "Peeling the onion" called student performance: An investigation into the factors affecting student performance in an introductory Accounting class. Review of Business, 33(1), 19-27.

Cortright, R. N., Lujan, H. L., Cox, J. H., \& DiCarlo, S. E. (2011). Does sex (female versus male) influence the impact of class attendance on examination performance? Advanced Physiological Education, 35(4), 416-420. https://doi.org/10.1152/advan.00021.2011

Dobkin, C., Gil, R., \& Marion, J. (2010). Skipping class in college and exam performance: Evidence from a regression discontinuity classroom experiment. Economics of Education Review, 29(4), 566-575. https://doi.org/10.1016/j.econedurev.2009.09.004

Du Plessis, A., Muller, H., \& Prinsloo, P. (2005). Determining the profile of the successful first-year Accounting student. South African Journal of Higher Education, 19(4), 684-698. https://doi.org/10.4314/sajhe.v19i4.25656

Durden, G. C., \& Ellis, L. V. (1995). The effects of attendance on student learning in principles of economics. The American Economic Review, 85(2), 343-346. https://doi.org/10.1080/758518985

Elger, D. (2007). Theory of performance. Faculty guidebook: A comprehensive tool for improving faculty performance, 4, 19-22.

Evans, M. (2000). Planning for the transition to tertiary study: A literature review. Journal of Institutional Research, 9(1), 1-13.

Higher education and training, White paper for post school education and training: Building an expanded, effective and integrated post-school system, Department of Higher education and training, South Africa, 2013.

Hoskins, S. L., Newstead, S. E., \& Dennis, I. (1997). Degree Performance as a Function of Age, Gender, Prior Qualifications and Discipline Studied. Assessment \& Evaluation in Higher Education, 22(3), 317-328. https://doi.org/10.1080/0260293970220305

Howie, S. J. (2003). Language and other background factors affecting secondary pupils' performance in Mathematics in South Africa. African Journal of Research in Mathematics, Science and Technology Education, 7(1), 1-20. https://doi.org/10.1080/10288457.2003.10740545

Jansen, J., \& de Villiers, C. (2015). Determinants of student performance in an Accounting degree programme. South African Journal of Accounting Research, 30(1), 1-28. https://doi.org/10.1080/10291954.2015.1019223

Johnson, D. L., Joyce, B. P., \& Sen, S. (2002). An analysis of student effort and performance in the finance principles course. Journal of Applied Finance, 12(2), 67-72.

Khuluvhe, M., \& Mathibe R. (2021). Fact Sheet- Throughput rate of national certificate vocational: For the period 2016 to 2018, Department of Higher Education and Training, 2021. http://hdl.voced.edu.au/10707/575999

Kukreja, G., \& Al Aali, M. H. (2013). The determinants of students' performance in introductory accounting courses: Evidence from Kingdom of Bahrain. Journal of Emerging Issues in Economics, Finance and Banking, 1(3), 183-201.

Management Accounting Handbook. (2015). Durban University of Technology: Faculty of Accounting and informatics.

Marburger, D. R. (2006). Does mandatory attendance improve student performance? The Journal of Economic Education, 37(2), 148-155. https://doi.org/10.3200/JECE.37.2.148-155

Marks, G. N. (2008). Accounting for the gender gaps in student performance in reading and Mathematics: Evidence from 31 countries. Oxford Review of Education, 34(1), 89-109. https://doi.org/10.1080/03054980701565279

McCubbin, I. (2003). An examination of criticism made of Tinto's student integration model of attrition (online). Available: http://www.psy.gla.ac.uk/ steve/localed/icubb.pdf. (Accessed 2 May 2015).

McCune, V., Hounsell, J., Christie, H., Cree, V. E., \& Tett, L. (2010). Mature and younger students' reasons for making the transition from further education into higher education. Teaching in Higher Education, 15(6), 691-702. https://doi.org/10.1080/13562517.2010.507303

Motowildo, S. J., Borman, W. C., \& Schmit, M. J. (1997). A theory of individual differences in task and contextual performance. Human Performance, 10(2), 71-83. https://doi.org/10.1207/s15327043hup1002_1 
Nyikahadzoi, L., Matamande, W., Taderera, E., \& Mandimika, E. (2013). Determinants of students' academic performance in four selected Accounting courses at University of Zimbabwe. Research in Higher Education Journal, 21, 22.

Paisey, C., \& Paisey, N. J. (2004). Student attendance in an accounting module-reasons for non-attendance and the effect on academic performance at a Scottish University. Accounting education, 13(sup1), 39-53. https://doi.org/10.1080/0963928042000310788

Papageorgiou, K., \& Halabi, A. K. (2014). Factors contributing toward student performance in a distance education accounting degree. Meditari Accounting Research, 22(2), 211-223. https://doi.org/10.1108/MEDAR-08-2013-0032

Rosenthal, A. S., Baker, K., \& Ginsburg, A. (1983). The effect of language background on achievement level and learning among elementary school students. Sociology of Education, 56(5), 157-169. https://doi.org/10.2307/2112545

Schmulian, A., \& Coetzee, S. (2011). Class absenteeism: reasons for non-attendance and the effect on academic performance. Accounting Research Journal, 24(2), 178-194. https://doi.org/10.1108/10309611111163718

Seidman, A. (1996). Retention revisited. College and University, 71(4), 18-20.

Sekaran, U., \& Bougie, R. (2010). Research Methods for Business. 5th ed. Haddington: John Wiley and Sons.

Stainbank, L. (2013). The impact of NSC Mathematics on the performance of first year commerce students. Alternation Special Edition: Trends in Management, Informatics and Research in a 21 st Century Digitally Connected World, 8, 107-121.

Steenkamp, L. P., Baard, R. S., \& Frick, B. L. (2009). Factors influencing success in first-year accounting at a South African university: A comparison between lecturers' assumptions and students' perceptions. South African Journal of Accounting Research, 23(1), 113-140. https://doi.org/10.1080/10291954.2009.11435142

Steinmayr, R., Meibner, A., Weidinger, A. F., \& Wirthwein, L. (2015). Academic achievement. Oxford Bibliographies, 1. https://doi.org/10.1093/obo/9780199756810-0108

Teixeira, A. A. C. (2013). The impact of class absenteeism on undergraduate's academic performance: Evidence from an elite economics school in Portugal. Economics and Management, 503, 1-17. https://doi.org/10.1080/14703297.2014.937730

Tinto, V. (1975). Dropout from higher education: A theoretical synthesis of recent research. Review of Educational Research, 45(1), 89-125. https://doi.org/10.3102/00346543045001089

Tinto, V. (1993). Leaving college: Rethinking the causes and cures of student attrition. Second edition. Chicago: University of Chicago Press. https://doi.org/10.7208/chicago/9780226922461.001.0001

Traphagan, T., Kucsera, J. V., \& Kishi, K. (2009). Impact of class lecture webcasting on attendance and learning. Educational Technology Research and Development, 58(1), 19-37. https://doi.org/10.1007/s11423-009-9128-7

\section{Copyrights}

Copyright for this article is retained by the author(s), with first publication rights granted to the journal.

This is an open-access article distributed under the terms and conditions of the Creative Commons Attribution license (http://creativecommons.org/licenses/by/4.0/). 